\title{
ANALISIS KUALITAS PELAYANAN TERHADAP KEPUASAN \\ NASABAH PT. WOM FINANCE WONOGIRI
}

\author{
Aris Susanto, Bambang Mursito, Sri Hartono
}

Fakultas Ekonomi, Universitas Islam Batik Surakarta

arsusanto17@gmail.com

\begin{abstract}
Analysis of Service Quality Towards Customer Satisfaction PT. WOM Finance Wonogiri. Thesis, Management Study Program (S1). Surakarta Batik Islamic University, 2019. This study aims to determine the effect of service quality consisting of tangibles, reliability, responsiveness, assurance, empathy simultaneously and partially on customer satisfaction at PT WOM Finance Wonogiri. This research uses quantitative research methods. Data sources used in this study were respondents or people who responded or answered the researchers' questions, namely customers of PT. WOM Finance Wonogiri. Data collection methods used observation, questionnaire, and documentation. This study uses classical assumption test techniques, multiple linear regression analysis, and hypothesis testing ( $t$ test, $f$ test, and coefficient of determination). The results of data analysis obtained there are tangibles, reliability, responsiveness, assurance, empathy effects simultaneously and partially to customer satisfaction at PT WOM Finance Wonogiri.
\end{abstract}

Keywords: tangibles, reliability, responsiveness, assurance, empathy (empathy), customer satisfaction

\section{PENDAHULUAN}

Sandang pangan dan papan merupakan kebutuhan manusia yang sangat penting sehingga dalam pemenuhannya selayaknya kita harus bekerja sangat keras untuk mendapatkan dana karena kondisi ekonomi saat ini terjadi perubahan yang signifikan.

Hal ini membuat terbukanya jalan untuk lembaga keuangan untuk memberikan produk dan jasanya melalui pinjaman/kredit. Dengan adanya kredit dan kemudahan proses untuk mendapatkan dana yang cepat maka hal ini sangat membantu konsumen yang kekurangan dana yang sifatnya mendesak.

Kepercayaan dan loyalitas konsumen ditimbulkan oleh kualitas layanan yang baik sehingga konsumen merasa puas. Kepuasan nasabah merupakan titik dimana apa yang diharapkan dan yang diterima nasabah itu sesuai atau melebihi angan-angannya. Jika nasabah menerima lebih dari harapannya dan menyatakan puas seyogyanya perusahaan harus meningkatkan kepuasan nasabah tersebut sehingga nasabah tidak meninggalkan perusahaannya.

Untuk mendapatkan kepuasan pelanggan kita harus memiliki beberapa dimensi kualitas pelayanan, meliputi: bukti fisik (tangible), keandalan (realibility), daya tanggap (responsiveness), jaminan (assurance), empati (empathy).

Untuk memudahkan kebutuhan manusia akan motor, maka PT. WOM Finance Cabang Wonogiri perusahaan yang bergerak dalam hal pembiayaan motor dan leasing memberikan 
kemudahan dalam permohonan pemakaian jasa pembiayaannya serta selalu meningkatkan kualitas pelayanannya untuk kepuasan pelanggannya.

Dimensi kualitas pelayanan seperti bukti fisik, keandalan, daya tanggap, jaminan dan empati berpengaruh terhadap perilaku pelanggan untuk menggunakan jasa PT. WOM Finance Cabang Wonogiri.

\section{TINJAUAN TEORITIS}

\section{Pengertian Kepuasan Konsumen}

Kepuasan konsumen merupakan hasil evaluasi dari perbandingan apa yang diharapkan dengan harpannya setelah melakukan pembelian (Zulian, 2015: 78).

\section{Pengertian Kualitas Layanan}

Zeithhaml, Parasuraman \& Berry (dalam Hardiansyah 2011:46). Dimensi kualitas pelayanan bisa dugunakan untuk melihat secara nyata perasaan konsumen terhadap kualitas pelayanan yang sudah diberikan, lima dimensi kualitas pelayanan tersebut yaitu:

1) Tangible (bukti fisik);

2) Reliability (kehandalan);

3) Responsiveness (daya tanggap);

4) Assurance (jaminan);

5) Emphaty (Empati).

\section{Kerangka Penelitian}

Untuk memperrmudah pemahaman dan memperjelas penelitian maka dapat digambarkan suatu kerangka penelitian teoriitis sebagai berikut:

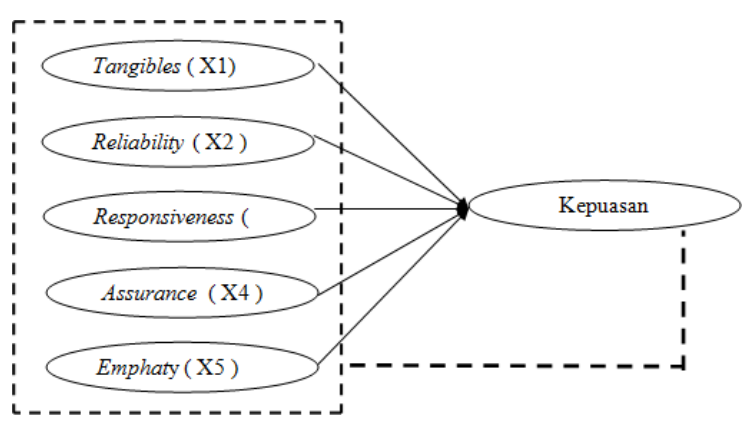

Berdasarkan bagan kerangka pemikiran diatas dapat dijelaskan bahwa variabel dependen disini adalah kepuasan. Selanjutnya variabel independentnya tangibles (X1), reliability (X2), responsiveness (X3), assurance (X4) dan emphaty (X5).

\section{Hipotesa}

1) Diduga bukti fisik (tangibles), daya tanggap (responsiveness), jaminan (assurance), empati (emphaty), kehandalan (reliability) berpengaruh signifikan terhadap kepuasan nasabah pada PT WOM Finance Wonogiri.

2) Diduga bukti fisik berpengaruh signifikan terhadap kepuasan nasabah pada PT 
WOM Finance Wonogiri.

3) Diduga kehandalan berpengaruh signifikan terhadap kepuasan nasabah pada PT WOM Finance Wonogiri.

4) Diduga daya tanggap berpengaruh signifikan terhadap kepuasan nasabah pada PT WOM Finance Wonogiri.

5) Diduga jaminan berpengaruh signifikan terhadap kepuasan nasabah pada PT WOM Finance Wonogiri.

6) Diduga empati berpengaruh signifikan terhadap kepuasan nasabah pada PT WOM Finance Wonogiri.

\section{METODE PENELITIAN}

\section{Sumber Data}

Sumber data yang digunakan dalam penelitian ini adalah responden atau orang yang merespon atau menjawab pertanyaan- pertanyaan peneliti, yaitu nasabah PT. WOM Finance Wonogiri.

\section{Metode Pengumpulan Data}

Penelitian ini menggunakan metode observasi, angket, dokumentasi.

\section{Model dan Teknis Analisis}

Metode yang digunakan dalam penelitian ini adalah kuantitatif, dengan pendekatan deskriptif.

Untuk menguji variabel $\mathrm{X}$ dan variabel $\mathrm{Y}$ ada pengaruh atau tidak, penelitian ini memakai regresi linear berganda. Berikut bentuk persamaan regresi dalam penelitian ini: (Sugiyono (2007: 275))

$\mathrm{Y}=\mathrm{a}+b_{1} X_{1}+b_{2} X_{2}+\mathrm{b}_{3} \mathrm{X}_{3}+b_{4} X_{4}+b_{5} X_{5}+\mathrm{e}($ Ghozali $(2006: 17))$

Keterrangan :

$\mathrm{Y} \quad=$ kepuasan nasabah

a $\quad=$ Konstanta

bn $\quad=$ Koefisien regresi variabel bebas ke-n

$\mathrm{X}_{1} \quad=$ Variabel bukti fisik (tangibles)

$\mathrm{X}_{2} \quad=$ Variabel kehandalan (reliability)

$\mathrm{X}_{3} \quad=$ Variabel daya tanggap

(responsiveness)

$\mathrm{X}_{4} \quad=$ Variabel jaminan (assurance)

$\mathrm{X}_{5} \quad=$ Variabel empati (emphaty)

e $\quad=$ Variabel pengganggu (error) 


\section{Pengujian Hipotesis}

Pengujian hipotesis menggunakan uji t, untuk mengetahui tingkat signiifikan kontribusi atau pengaruh varriabel bebas yang berpengaruh secara sendiri terhadap variabel terikat. Apabila hasil uji $t$ dengan nilai signifikan $<0,05$, berarti variabel secara sendiri-sendiri terdapat pengaruh signifikan terhadap variabel terikat.

\section{HASIL PENELITIAN DAN PEMBAHASAN}

Berdasarkan hipotesis yang disampaikan "Diduga variabel bukti fisik, kehandalan, keresponsifan, jaminan dan empati berpengaruh secara signifikan terhadap variabel kepuasan nasabah" terbukti, ditunjukkan dengan hasil analisis regresi linier berganda sebagai berikut:

$\mathrm{Y}=0,150 \mathrm{X}_{1}+0,514 \mathrm{X}_{2}+0,133 \mathrm{X}_{3}+0,183 \mathrm{X}_{4}+0,243 \mathrm{X}_{5}$

Hasil perhitungan menggunakan SPSS 17 didapatkan hasil uji t dan disajikan dalam table berikut:

\begin{tabular}{|l|l|l|l|}
\hline No & Variabel & thitung & Sig. \\
\hline 1 & Tangible & 2,087 & .040 \\
\hline 2 & Reliability & 7,869 & .000 \\
\hline 3 & Responsiveness & 2,200 & .030 \\
\hline 4 & Assurance & 2,478 & .015 \\
\hline 5 & Emphaty & 3,176 & .002 \\
\hline
\end{tabular}

Berdasarkan tabel diatas diperoleh variable tangible sebesar $t_{\text {hitung }}=2,087>t_{\text {tabel }}=1,66$, maka Ho ditolak, berarti tangible terdapat pengaruh yang signifikan terhadap kepuasan nasabah, variabel reliability sebesar $\mathrm{t}_{\text {hitung }}=7,869>\mathrm{t}_{\text {tabel }}=1,66$, maka Ho ditolak berarti ada pengaruh yang signifikan reliability terhadap kepuasan nasabah, variabel responsiveness sebesar $t_{\text {hitung }}=2,200>\mathrm{t}_{\text {tabel }}=1,66$, maka Ho ditolak berarti terdapat pengaruh yang signifikan responsiveness terhadap kepuasan nasabah, variabel assurance sebesar $t_{\text {hitung }}=2,478>t_{\text {tabel }}=1,66$, maka Ho ditolak brarti terdapat pengaruh yang signifikan assurance terhadap kepuasan nasabah, variabel empathy sebesar $t_{\text {hitung }}=3,176$ $>\mathrm{t}_{\text {tabel }}=1,66$, maka Ho ditolak berarti terdapat pengaruh yang signifikan empathy terhadap kepuasan nasabah.

\section{Pembahasan}

Hasil analisis deskriptif dan pengujian hipotesis melihatkan bahwa bukti fisik (tangibles), kehandalan (reliability), daya tanggap (responsiveness), jaminan (assurance), empati (emphaty) secara simultan dan parsial berpengaruh terhadap kepuasan nasabah pada PT WOM Finance Wonogiri 


\section{KESIMPULAN DAN SARAN}

\section{Kesimpulan}

1) Ada pengaruh bukti fisik (tangibles), kehandalan (reliability), daya tanggap (responsiveness), jaminan (assurance), empati (emphaty) secara simultan terhadap kepuasan nasabah pada PT WOM Finance Wonogiri

2) Ada pengaruh signifikan bukti fisik terhadap kepuasan nasabah pada PT WOM Finance Wonogiri.

3) Ada pengaruh signifikan kehandalan terhadap kepuasan nasabah pada PT WOM Finance Wonogiri.

4) Ada pengaruh signifikan keresponsifan terhadap kepuasan nasabah pada PT WOM Finance Wonogiri.

5) Ada pengaruh signifikan jaminan terhadap kepuasan nasabah pada PT WOM Finance Wonogiri.

6) Ada pengaruh signifikan empati terhadap kepuasan nasabah pada PT WOM Finance Wonogiri.

\section{Saran}

Berdasarkan analisis dan kesimpulan, maka dapat disampaikan saran: Manajemen PT WOM Finance Wonogiri dalam usaha meningkatkan kepuasan nasabah, maka perusahaan seyogyanya memperhatikan faktor-faktor yang dapat mempengaruhi kepuasan seperti dalam model.

\section{DAFTAR PUSTAKA}

Ghozali, Imam. 2006. Aplikasi Analisis Multivariated Dengan Program SPSS. Edisi Cetakan IV. Semarang: Badan Penerbit Universitas Diponegoro.

Hardiansyah. 2011. Kualitas Pelayanan Publik. Yogyakarta: Gaya Media

Sugiyono. 2009. Metode Penelitian Administrasi dilengkapi Dengan Metode R\&D. Bandung: Alfabeta.

Zulian, Y., 2015.Manajemen Kuantitatif Untuk Bisnis (Operation Research), Yogyakarta : BPFE-UGM. 